Volume 9, No.1, January - February 2020

International Journal of Advanced Trends in Computer Science and Engineering

Available Online at http://www.warse.org/IJATCSE/static/pdf/file/ijatcse53912020.pdf

https://doi.org/10.30534/ijatcse/2020/53912020

\title{
Examining Students' Satisfaction and Learning Autonomy through Web-Based Courses
}

\author{
Hassan Abuhassna, Megat Aman Zahiri Megat Zakaria, Noraffandy Yahya, Azlina Bt. Mohd Kosnin \\ Waleed Mugahed Al-Rahmi \\ Faculty of Social Sciences \& Humanities, School of Education, Universiti Teknologi Malaysia, 81310, UTM Skudai, Johor, \\ Malaysia, mahassan@utm.my \\ Faculty of Social Sciences \& Humanities, School of Education, Universiti Teknologi Malaysia, 81310, UTM Skudai, Johor, \\ Malaysia,megataman@utm.my \\ Faculty of Social Sciences \& Humanities, School of Education, Universiti Teknologi Malaysia, 81310, UTM Skudai, Johor, \\ Malaysia,p-afandy@utm.my \\ Faculty of Social Sciences \& Humanities, School of Education, Universiti Teknologi Malaysia, 81310, UTM Skudai, Johor, \\ Malaysia, p-azlina@utm.my \\ Faculty of Social Sciences \& Humanities, School of Education, Universiti Teknologi Malaysia, 81310, UTM Skudai, Johor, \\ Malaysia, waleed.alrahmi@yahoo.com
}

\begin{abstract}
Web-based learning settings are more convenient than face-to-face learning settings, whereas they present additional opportunities for education that occurs in various environments. However, many educational institutions specially in the third world countries are not prepared for the challenges involved in offering quality Web-based courses. This research aimed to identify Web based courses effects on students' satisfaction and learning autonomy based on Moore's transactional distance theory (TDT) through web-based courses. Therefore, this study seeks to develop a model to measure students' background, students' experience, students' learning autonomy, students' dialogue with their instructor, and students' satisfaction. A quantitative approach was implemented in this study. Whereas a questionnaire was the major data collection tool, thus it was distributed amongst 377 learners. Furthermore, the obtained data was examined using AMOS-SEM. More specifically, SEM was applied for the independent variables which were dependent in a subsequent dependent correlation. The results showed that students' background, students' experience, students' learning autonomy, and students' dialogue there were positive and significant relationship with students' satisfaction. Additionally, the students had a feeling of satisfaction. Therefore, the results proposed a guideline for instructors of institutions of higher learning in Palestine to design and create webbased courses that would increase students' autonomy and satisfaction in the Web-based learning settings.
\end{abstract}

Key words: Structural Equation Modeling (SEM), Web-based courses, online courses, teaching and learning strategies, classroom improvement

\section{INTRODUCTION}

Web-based environments and online learners have historically faced several challenges, including unsatisfying and impersonal interactions [1],[2],[3]. Scholars have highlighted that learners of online learning settings pursue the flexibility in timing of online learning settings, rather than physical interactions with their instructors [4] On the other hand, online learning courses are recognised by their flexibility, many online learners are yet to deal with the basic requirements, knowledge and experience needed to be successful. In conferring the best practices of online learning, Scholars stated the following advantages: reducing the traveling costs and time; access more opportunities to and collaborate with professional experts globally; giving students more flexibility on accessing courses at their own convenient time and place and providing them with diverse adjustments to the subject and content [5]. Research indicated that there is continual evolution in the technologies that develop improvements to learning; however, the process of redesigning the technology content can help to improve a course's results. In addition, the anonymous online environment nature could allow shy or socially anxious students, who would otherwise be reluctant to join face-to-face sessions, to take a place in online education settings, whereas they are physically separated. Lastly, the advanced software and technology might let the instructors, learners, along with the administrators to collect data, feedback, as well as assessment about their online learning practices and massive open online courses (MOOCs) [6],[7],[8]. Nevertheless, many learners and scholars observed that Web-based learning courses lack interaction. Consequently, improved strategies of teaching and learning are needed in order to provide students with a convenience Web-based learning courses and also with a real-time access interaction with their instructor and class colleagues that best simulates the traditional classroom setting. As a matter of 
fact, Learners have enquired for more opportunities to interact with their colleagues' synchronously [9]. In this paper, we aim to present a guideline of utilizing Web-based learning environments on students' satisfaction based on more TDT through web-based courses. Although online learning has existed for nearly 100 years, web-based (online) courses and programs are relatively new options. In the past decade, online learning has gained widespread acceptance by higher education and the public it serves [10]. Acceptance is especially evident in community colleges, one of the largest providers of online courses. Web-based courses offer fresh instructive opportunities for learners who are not able to join classes because of family responsibilities and other problems that is related to traveling abroad. This situation is principally correct for community college students [11], who are usually non-traditional adult learners; these learners are appealed to the easiness and suitability of online courses provide [12]. A noteworthy number of community college students encounter the extra obstacle of arriving unprepared for college-level classes. However, many institutions are not prepared for the challenges involved in offering quality web-based course; especially in a developing county, it is a new phenomenon in the education system. In addition, there is a shortage of

This study was guided by Moore transactional distance theory [17], [18] paired with its important dimension of Learner Autonomy [19], [20], has risen above the rest. This theory has been favoured over others in empirical research and several researchers have used it as the foundation of their work [21], [22], [23], [24], [25], [26], [27] [28], [29], [30], [31]. Discussion of its usefulness, validity and make up are more prominent in the literature than that of other theories [32], [33], [34], [35], [36], [37], [38] [39]. Online learning system is made up of the processes of remote education "containing teaching, communications, learning, design and management" [40]. Transactional Distance and Learner Autonomy theory strengthens this view by distinguishing itself from other theories in its comprehensive view of the systems involved in teaching, learning and the institution [40]. Moore transactional distance theory (TDT) is often at the core of research in the domain of online learning and it has been used as the theoretic based for this research [17], [41]. This theory is founded experience on improving web-based course, as the online environment develops; it offers terrible trials to higher education, [13]. Moreover, the problem of successful completion in online courses persists for reasons that have essentially not changed over the last 2 decades. A few of these reasons are lack of contact with the instructor, poor course design, ineffective online teaching practices, and lack of involvement/engagement [14]. Inspiring learners to actively take part besides impacting on the curriculum design may require a re-setting instructor and learner roles, thus, in turn influences social interactions and thus the hierarchy [15]. Additionally, higher education is constructed on the university teacher perspective of-identifying what is important for learners, what they can be taught along with what they should do to accomplish the objectives required [16]. Teacher dominance culture in higher education can impede instructors' along with learners' enhancement of new roles along with seeing education from any other perceptions. Nonetheless, there is a necessity to change the traditional roles of both instructor and student, a task that 'supports a greater democratisation of the learning journey [16].

\section{THEORETICAL MODEL}

on the notion that the corporeal separation of the student and instructor can lead to communication gaps that generate misinterpretations and feelings of separation [42]. The roots of TDT can be searched back to John Dewey, a renowned donor to the domain of child development. In line with the TDT, he supposed that interactions and situations are closely attached, and that an experience is principally affected by the contract between a person and his environment [43], [44]. In his book Experience and Education, based on [45] describes that the transactions occurring between a person and his or her environment, which is a condition interrelating with the person's personal needs, are what build the experience [45]. Though the origins of TDT can be traced in the work of Dewey, it is Michael Moore who is identified as the innovator of this theory that first appeared in 1972. In his study and development of the theory, he acknowledged three main components of TDT that work as the base for much of the research on online learning environments. See Figure 1. 


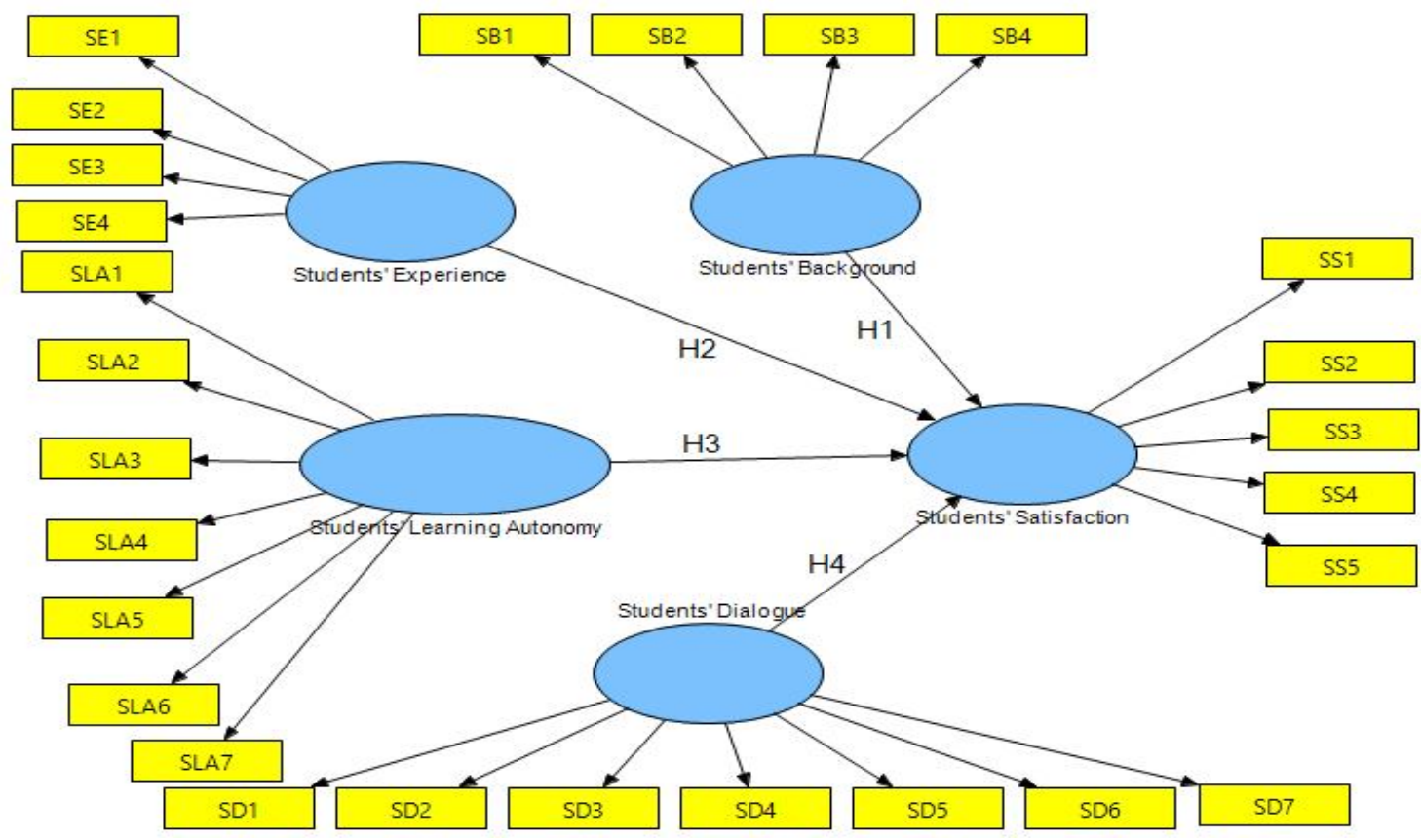

Figure 1: Research Model

\subsection{Students' Background}

Based on [46] faculty should establish an immediately evident presence and rapport in the online web-based courses. [47] stated that, the participation in a web-based environment includes obstacles in different areas, Disconnectedness, navigation and participation. Which explain that in developing an online, or distance environment students should be provided to online learning order to be familiar and gain the best results. [48] finding claimed that facilities provided by the faculty and students background play a crucial role in distance courses. It also supports the current importance and growth of LMSs in online courses. Perhaps institutions should struggle to provide faculty training to make sure that faculty is aware with flexibilities of all the online courses that are provided to meet the requirements of both instructors and students. When this training implemented properly, perhaps could provide faculty with more flexible means of engaging and interacting students and ultimately contribute in reducing the TD for their students in a course, particularly for online courses. In addition, they indicated that technical support, adequacy of equipment, and opportunity for students-to student collaboration played a major role in influencing their decisions to participate in online learning environments. The responses are consistent with existing research that has shown that faculty and administrative support tend to influence learner involvement in web-based course. The finding of [49], [50], [51], [52], [53]; [54], [55] revealed that Facilities provided by the faculty increases students background towards online learning, interaction between students and faculty in web-based course and it has the strongest correlation with student satisfaction with the college experience than any other type of involvement.

Hypothesis 1: There is an important association amongst students' background and students' satisfaction.

\subsection{Students' Experience}

The learners who participated in the web-based course before felt more familiar and connected to the course [56], [57], [58]. Results of [47] study, the students were asked: "Have you taken any other online courses at this college? If so, how involved did you feel in this course as compared to other online courses you have taken?". (33.3\%) of the participants indicated that they have taken an online course before. Those students also indicated that the felt somewhat involved in the online course, as they have participated in a similar setting before. In addition, [58] study on Examining aspects affecting ESL (English as Second Language) university undergraduates' acceptance along with Modular Object- Oriented Dynamic Learning Environment (Moodle) use. His study finding reveals that learners who before utilized Moodle or any other LMSs promptly agreed or constantly resisted the procedure which is based on their prior thoughts of Moodle or any other LMSs. Some earlier studies regarding technology acceptance behaviour had stated the belief of "conformity," which indicates the level of consideration that any specific innovation is 
coherent with existing practices, experiences, values and needs [59]; [60]; [61], [62]. In addition. responses to the questionnaire in [63] study showed that students' personal attitudes toward online learning ranged from very positive to somewhat positive. According to [64], [65], [66], [67], [68] most students who had prior experience with webbased course manage to exhibit positive attitudes toward web-based course, Most significantly, earlier research have showed that learners greater Internet knowledge has a considerable positive impact on their attitudes about the Internet. The students responding to the questionnaire, all of whom were distance learners, were so inclined. In addition, the one factor that was in the study to be significantly related to student participation in webbased course was learners' attitudes toward webbased course. [63] study that argued that web-based course completers perceived that prior experience with computers and the Internet were important factors that influenced student participation in webbased course. prior experience with computers and the internet to influence student participation in web-based course Because almost all the students responding to the questionnaire rated themselves very high on computer use and internet use, no meaningful comparisons could be made on this factor [69].

Hypothesis 2: There is an important association amongst students' experience and students' satisfaction.

\subsection{Students' Learning Autonomy}

The tertiary constituent of the theory of transactional distance is the concept of learning autonomy [41]. Learning autonomy discusses the extent of student freedom and self-handling relative to selecting objectives, looking for help when desired, handling time, applying learning schemes and assessing results as desired for the course. The theory offers that courses will differ in the degree of desired autonomy, on the basis of course format and dialogue. The conception of autonomy is coordinated with other theories that connect to learner inspiration and aptitude to work autonomously, such as self-determination [70], [71] and self-directed learning [57]. Several research attempts are autonomous to be success factor for online learning settings [72],[73], [74], [75]. All courses require some level of learner autonomy, regardless of the delivery modality. However, by applying the theory of transactional distance, may require a higher level of learning autonomy. Students in a web-based course must establish weekly goals for work completion that are not driven by the same day/time requirements of a face-to-face course. They must establish their own schedule and then execute the learning activities on their own, not in the context of a classroom setting.
The learning activities are established and although a student may have flexibility relative to the time, they complete them, as well as in which order, the learning activities themselves have no flexibility in design and no interaction with faculty for those structured learning components. Lastly, students must complete and submit assessments (quizzes and midterm exams) electronically on their own, without the benefit of a faculty member handing out an assignment and collecting it during class time. Each of these elements of student behaviour relate to Moore's construct of autonomy.

Hypothesis 3: There is an important association amongst students' learning autonomy and students' satisfaction.

\subsection{Students' Dialogue}

The second component of TDT relates to the concept of dialogue [41]. Dialogue refers to interactive relations intended for the creation of knowledge specifically between learner and instructor [41]. The intensity of communication between student and instructor can be varied across any delivery modality comprising face-to-face and mixed courses. Though Moore restricted his conception of dialogue to learner-tutor interaction, later theorizers have extended the conception of communication and dialogue to include studentstudent communication as a noteworthy component [76], [70], [57], [77]This concept coordinates with current theory, comprising the community of inquiry framework, which highlights social, teaching and cognitive presence [57] Participants in the study will complete a survey that addresses various aspects of student-student as well as student-teacher dialogue, which will be used to evaluate and interpret the study results. Student satisfaction with dialogue and interaction within the course will be a factor that contributes to the analysis of student satisfaction.

Hypothesis 4: There is an important association amongst students' dialogue and students' satisfaction.

\subsection{Students' Satisfaction}

Satisfaction is a level factor of expectation and performance. Cultural variations effect the level of students' satisfaction concerning their perception of the services [78]. A supportive learning framework can enhance the learner's satisfaction and success with online learning environments. The satisfaction level of learners is the edge between anticipation level and the present findings. Satisfaction of learner is a result of an enjoyment and achievement and is, thus, "a successful and an enjoyable experience" [78]. Learner's satisfaction is an essential measure the educational program quality, besides being considered as a significant element to 
the completion of course. In a most of cases, learners in post-secondary education programs leave their education for the discontent with their educational programmes. The learner satisfaction builds the needed self-confidence, which will aid the learners in becoming more confident, develop required skills in their professional life, and acquire knowledge in an efficient cycle. According to [80] the satisfaction of a learner is felt when there is a perceived learner-educator interaction which happening in the classroom or virtual environment [80]. Learners' experiences on their lives at university with the experience's combination, most likely will affect the overall satisfaction with the institution. Educational establishments featured with innovation and success; seek to increase satisfaction because these establishments realize its worth in developing their images and increasing learners' abilities. Learner's satisfaction of the can enhance and improve the ability of these educational establishments to make the right decisions about improving and enhancing the programmes of web-based course. Satisfaction is considered -beside the learner's autonomy- one of the most important tool for measurements that defines web-based course quality [81], [82],[83]. Regardless of the used environment, the quality of courses' distribution is very important according to the above. The satisfaction of the learner is a primary need in the process of education. It is confirmed that in online environments, learners' the satisfaction is a basic condition for effective application [82]. The learner's satisfaction usually points to learner's delight attained from using an instructive method in online learning environments. [84] found that "the LMS view by more students enhances their satisfaction with the system" and also "technical support has contributed to learner's satisfaction with LMS" (p.193). [85] in a same way, asserted that "the easier learners perceived LMS, the more readily learners accepted LMS" and that "instructors' help in using LMSs positively affected learners' acceptance of LMSs" (p.1091). Moreover, in his seminal work, [86] studied data collected from nearly 25,000 students at over 200 higher education institutions. Astin posited that frequent interaction between students and faculty in distance education courses has been more strongly correlated with student satisfaction with the college experience than any other type of involvement. According to the results of [87] study, learners satisfaction values in courses conveyed all through online environments based on the sex variable show that there was no difference among the Enrolment components, System Evaluation and Support considering the sex variable. Furthermore, whereas learner's satisfaction levels values in courses conveyed via distance with respect to participation variable show that there was no difference among the System Evaluation and
Enrolment components considering the participation variable; there was a significant difference for the Support dimension. In [88] study titled "Education Faculty Students' Level of Satisfaction with the Computer-Assisted online System (Moodle)", it was found that learners discover courses conveyed over online environments effective. According to [88], [89], [90] good collaborations in the community besides obtaining responses to the learning requirements will enhance the motivation along with learning satisfaction. Also, to do that, established online communication self-efficacy of the students might be a significant issue. Since, to build up effective connections with different members in the essential network, learners are expected to have created online relational abilities. As for [91] learners who can communicate successfully and comfortably in online settings can be more effective in online settings. In the same way, findings of this research show that communication online has positively influenced satisfaction with regard to the course in instruction model. Research model discussed by [92] for English lessons of middle school students also supports these results. According [92] it was discovered that there was a positive correlation among communication self-efficacy along with technology self-efficacy with expectations as well as motivation.

\section{RESEARCH METHODOLOGY}

The participants of this study comprised the students enrolled to the course "Education Psychology", in the University College of Applied Sciences (UCAS) in Palestine. As a start of data collection process, learners were requested to fill a questionnaire. Thus, the questionnaire intended at assessing the impact of every single factor along with examining the hypotheses of this study. Thus, the questionnaire was distributed amongst 377 learners whereas it consists of 27 items such as students' background (SB), students' experience (SE), students 'learning autonomy (SLA), students' dialogue (SD), and students' satisfaction (SS). Learners feedback was very valuable to the questionnaire. This study aimed at revealing the association among the different independent and dependent variables related to web-based courses to improve students' satisfaction and autonomy based on Moore's transactional distance theory (TDT). The questionnaires were distributed randomly to University College of Applied Sciences (UCAS) students in Palestine. Data analysis was performed via IBM SPSS Version 20 along with Structural Equation Modeling (Smart PLS-SEM). Questionnaires were consisted of 27 items and it was planned and administered amongst all learners. For students' background and students' 
experience factors four items was measured from [47], [56], [57], and students 'learning autonomy seven items was measured from [93], [94] also, students' dialogue seven items were measured from [41]. Finally, students' satisfaction five items were measured from [50]. The following parts present details of data analyses along with factors of research that were formed regarding the objectives of the research Additionally, the obtained Cronbach's alpha of the instrument validity and reliability was observed to be 0.917 .

\section{RESULTS AND ANALYSIS}

Cronbach's Alpha reliability coefficient result was 0.918 regarding the (students' background, students' experience, learning autonomy, students' dialogue and students' satisfaction). Furthermore, The discriminant validity (DV) evaluation was performed throughout using three criteria specifically: index amongst variables which must be lower than 0.80 [95] the average variance extracted (AVE) each construct value that demands to be above or equal to 0.50 , along with square of (AVE) of each construct that must be higher than, in value, than the inter construct correlations (IC) associated with the factor [88]. Additionally, crematory factor analysis (CFA) findings with factor loading (FL) must be 0.70 or higher whilst the findings of Cronbach's Alpha (CA) were found to be $\geq 0.70$ [95]. Thus, researchers of this study additionally add that composite reliability (CR) must be $\geq 0.70$.

\subsection{Measurement Model and Instrumentation}

Firstly, the Partial Least Square use is the first stage of the assertion of the dependability and legitimacy of the model. Basic Equations Modeling (PLS-SEM), Smart PLS 2.0. Additionally, to affirm the model's fitness integrity preceding theories were utilized. Similarly, legitimacy build that spreads components loadings; composite unwavering quality, Cronbach's alpha, and merging legitimacy was established. Thus, the suggestion presented by [96], regarding using the standard test to affirm discriminant legitimacy was applied.

\subsection{Construct Validity of the Measurements}

Build legitimacy is described as the degree to which the things are used to measure a component can properly measure the concept they were supposed to measure [95]. The whole things utilized to measure the develops must stack fundamentally to their individual develops rather than different builds. Thus, this was assured by leading an systematic audit of writing in the mission to provide things that have as of now been set up and tried by previous writers. Moreover, On the premise of the component analysis, it was affirmed that things were relatively named to their develops as they demonstrated high loadings on them stood out from several develops (See Table 1).

Table 1: Items loading and cross-loadings

\begin{tabular}{|l|l|l|l|l|l|l|}
\hline Factors & Items & $\begin{array}{l}\text { Students' } \\
\text { Dialogue }\end{array}$ & $\begin{array}{l}\text { Students' } \\
\text { Learning } \\
\text { Autonomy }\end{array}$ & $\begin{array}{l}\text { Students' } \\
\text { Background }\end{array}$ & $\begin{array}{l}\text { Students' } \\
\text { Experience }\end{array}$ & $\begin{array}{l}\text { Students' } \\
\text { Satisfaction }\end{array}$ \\
\hline \multirow{4}{*}{$\begin{array}{l}\text { Students' } \\
\text { Dialogue }\end{array}$} & SD1 & 0.766684 & 0.129606 & 0.258520 & 0.169931 & 0.377273 \\
\cline { 2 - 7 } & SD2 & 0.810423 & 0.196949 & 0.166132 & 0.185860 & 0.439062 \\
\cline { 2 - 7 } & SD3 & 0.824195 & 0.146718 & 0.244462 & 0.176156 & 0.423304 \\
\cline { 2 - 7 } & SD4 & 0.809179 & 0.214540 & 0.293333 & 0.186719 & 0.479866 \\
\cline { 2 - 7 } & SD5 & 0.865018 & 0.141774 & 0.248393 & 0.166647 & 0.412450 \\
\cline { 2 - 7 } & SD6 & 0.827355 & 0.122166 & 0.271221 & 0.143588 & 0.464061 \\
\cline { 2 - 7 } & SD7 & 0.735755 & 0.408108 & 0.326255 & 0.353889 & 0.495386 \\
\hline \multirow{4}{*}{$\begin{array}{l}\text { Learning } \\
\text { Autonomy }\end{array}$} & SLA1 & 0.313858 & 0.766462 & 0.480386 & 0.571550 & 0.359743 \\
\cline { 2 - 7 } & SLA2 & 0.184313 & 0.884475 & 0.457898 & 0.692526 & 0.335112 \\
\cline { 2 - 7 } & SLA3 & 0.190353 & 0.839298 & 0.318282 & 0.560285 & 0.336182 \\
\cline { 2 - 7 } & SLA4 & 0.174232 & 0.862853 & 0.345214 & 0.620850 & 0.286597 \\
\cline { 2 - 7 } & SLA5 & 0.175263 & 0.908527 & 0.432597 & 0.657042 & 0.286999 \\
\cline { 2 - 7 } & SLA6 & 0.176684 & 0.859476 & 0.446922 & 0.613134 & 0.241405 \\
\cline { 2 - 7 } & SLA7 & 0.219879 & 0.774965 & 0.498046 & 0.576298 & 0.303072 \\
\hline \multirow{3}{*}{$\begin{array}{l}\text { Students' } \\
\text { Background }\end{array}$} & SB2 & 0.327883 & 0.272683 & 0.777751 & 0.348309 & 0.273509 \\
\cline { 2 - 7 } & SB3 & 0.157501 & 0.554579 & 0.686504 & 0.680311 & 0.236997 \\
\cline { 2 - 7 } & SB4 & 0.215331 & 0.493464 & 0.764365 & 0.650782 & 0.241182 \\
\cline { 2 - 7 } & SB5 & 0.271506 & 0.295684 & 0.820035 & 0.333697 & 0.342471 \\
\hline \multirow{3}{*}{$\begin{array}{l}\text { Students' } \\
\text { Experience }\end{array}$} & SE1 & 0.248219 & 0.545109 & 0.521908 & 0.795708 & 0.241199 \\
\cline { 2 - 7 } & SE2 & 0.235108 & 0.533919 & 0.583474 & 0.828926 & 0.335190 \\
\cline { 2 - 7 } & SE3 & 0.203001 & 0.629485 & 0.405671 & 0.806790 & 0.244513 \\
\hline
\end{tabular}




\begin{tabular}{|l|l|l|l|l|l|l|}
\hline & SE4 & 0.093850 & 0.677749 & 0.486717 & 0.789382 & 0.212468 \\
\hline \multirow{3}{*}{$\begin{array}{l}\text { Students' } \\
\text { Satisfaction }\end{array}$} & SS1 & 0.443215 & 0.346542 & 0.325631 & 0.299072 & 0.843339 \\
\cline { 2 - 7 } & SS2 & 0.466028 & 0.348471 & 0.320651 & 0.339369 & 0.806393 \\
\cline { 2 - 7 } & SS3 & 0.444689 & 0.273763 & 0.302299 & 0.218381 & 0.835134 \\
\cline { 2 - 7 } & SS4 & 0.468515 & 0.247564 & 0.266594 & 0.226705 & 0.805944 \\
\cline { 2 - 7 } & SS5 & 0.446400 & 0.300052 & 0.277958 & 0.263435 & 0.813509 \\
\hline
\end{tabular}

\subsection{Convergent Validity of the Measurements}

The reliability of composite values varied from 0.945171 to 0.847911 then they were all over throughout the proposed cut-off estimation of 0.70 , along with Cronbach values differing from 0.932094 to 0.822651 , throughout the proposed cut-off estimation of 0.60 . Additionally, the average change eliminated (AVE) values differed from 0.711912 to 0.583224 (all surpassed the cut-off estimation of 0.5), with critical element loadings surpassing 0.50 . Thus, these qualities agreed with the prescribed an incentive by [96] and [95]. Table 2 represents the CFA findings of the measurement model.

Table 2: Convergent validity

\begin{tabular}{|c|c|c|c|c|c|}
\hline Factors & Items & $\begin{array}{l}\text { Factors } \\
\text { Loading }\end{array}$ & $\begin{array}{l}\text { Cronbach's } \\
\text { Alpha }\end{array}$ & $\begin{array}{l}\text { Composite } \\
\text { Reliability }\end{array}$ & $\overline{A V E}$ \\
\hline \multirow{7}{*}{ Students' Dialogue } & SD1 & 0.766684 & \multirow{7}{*}{0.910074} & \multirow{7}{*}{0.928529} & \multirow{7}{*}{0.650395} \\
\hline & SD2 & 0.810423 & & & \\
\hline & SD3 & 0.824195 & & & \\
\hline & SD4 & 0.809179 & & & \\
\hline & SD5 & 0.865018 & & & \\
\hline & SD6 & 0.827355 & & & \\
\hline & SD7 & 0.735755 & & & \\
\hline \multirow{7}{*}{$\begin{array}{l}\text { Students' Learning } \\
\text { Autonomy }\end{array}$} & SLA1 & 0.766462 & \multirow{7}{*}{0.932094} & \multirow{7}{*}{0.945171} & \multirow{7}{*}{0.711912} \\
\hline & SLA2 & 0.884475 & & & \\
\hline & SLA3 & 0.839298 & & & \\
\hline & SLA4 & 0.862853 & & & \\
\hline & SLA5 & 0.908527 & & & \\
\hline & SLA6 & 0.859476 & & & \\
\hline & SLA7 & 0.774965 & & & \\
\hline \multirow{4}{*}{$\begin{array}{l}\text { Students' } \\
\text { Background }\end{array}$} & SB2 & 0.777751 & \multirow{4}{*}{0.863770} & \multirow{4}{*}{0.847911} & \multirow{4}{*}{0.583224} \\
\hline & SB3 & 0.686504 & & & \\
\hline & SB4 & 0.764365 & & & \\
\hline & SB5 & 0.820035 & & & \\
\hline \multirow{4}{*}{$\begin{array}{l}\text { Students' } \\
\text { Experience }\end{array}$} & SE1 & 0.795708 & \multirow{4}{*}{0.822651} & \multirow{4}{*}{0.880664} & \multirow{4}{*}{0.648576} \\
\hline & SE2 & 0.828926 & & & \\
\hline & SE3 & 0.806790 & & & \\
\hline & SE4 & 0.789382 & & & \\
\hline \multirow{5}{*}{$\begin{array}{l}\text { Students' } \\
\text { Satisfaction }\end{array}$} & SS1 & 0.843339 & \multirow{5}{*}{0.879041} & \multirow{5}{*}{0.911789} & \multirow{5}{*}{0.674056} \\
\hline & SS2 & 0.806393 & & & \\
\hline & SS3 & 0.835134 & & & \\
\hline & SS4 & 0.805944 & & & \\
\hline & SS5 & 0.813509 & & & \\
\hline
\end{tabular}

\subsection{Discriminant Validity of Measures}

The degree to which an idea and its indicators go astray from an additional idea and it's markers is examined by discriminant legitimacy [97] The AVE esteem is well over 0.50 and is critical at $\mathrm{p}=0.001$ in addition, this displays that discriminant legitimacy is strengthened for the entire builds [96] additionally, [95] simplified the associations among things in two develop ought not to surpass the square base of the normal fluctuation shared by a solitary develops things (See Table 3). 
Table 3: Latent Variable Correlations

\begin{tabular}{|l|l|l|l|l|l|}
\hline Factors & SLA & SB & SD & SE & SS \\
\hline Students' Learning Autonomy & 1.000000 & & & & \\
\hline Students' Background & 0.507121 & 1.000000 & & & \\
\hline Students' Dialogue & 0.248351 & 0.323483 & 1.000000 & & \\
\hline Students' Experience & 0.728785 & 0.627798 & 0.249475 & 1.000000 & \\
\hline Students' Satisfaction & 0.370908 & 0.364533 & 0.552950 & 0.329985 & 1.000000 \\
\hline
\end{tabular}

\subsection{Analysis of the Structural Model}

Accordingly, once the demonstrated estimation assurance of the integrity was asserted, the subsequent stride included the conjectured connections testing amongst the builds. Thus, the specialist employed the SmartPLS 2.0 whereas the model was examined by leading the PLS estimate. Additionally, the way coefficients were then released as portrayed in Figure 2. Figures 3 thus, show the theories on table 4 .

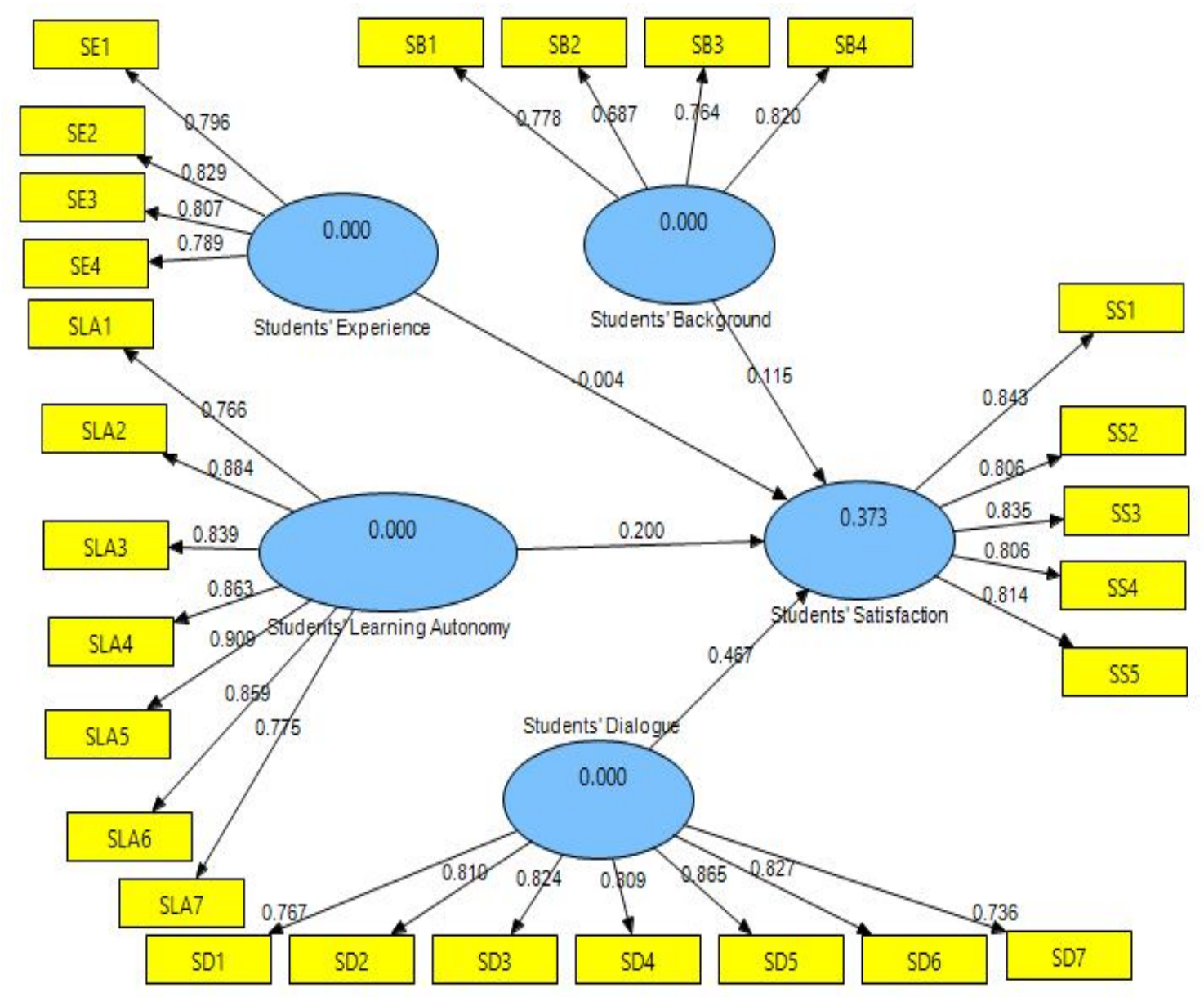

Figure. 2: Path Coefficients Results 


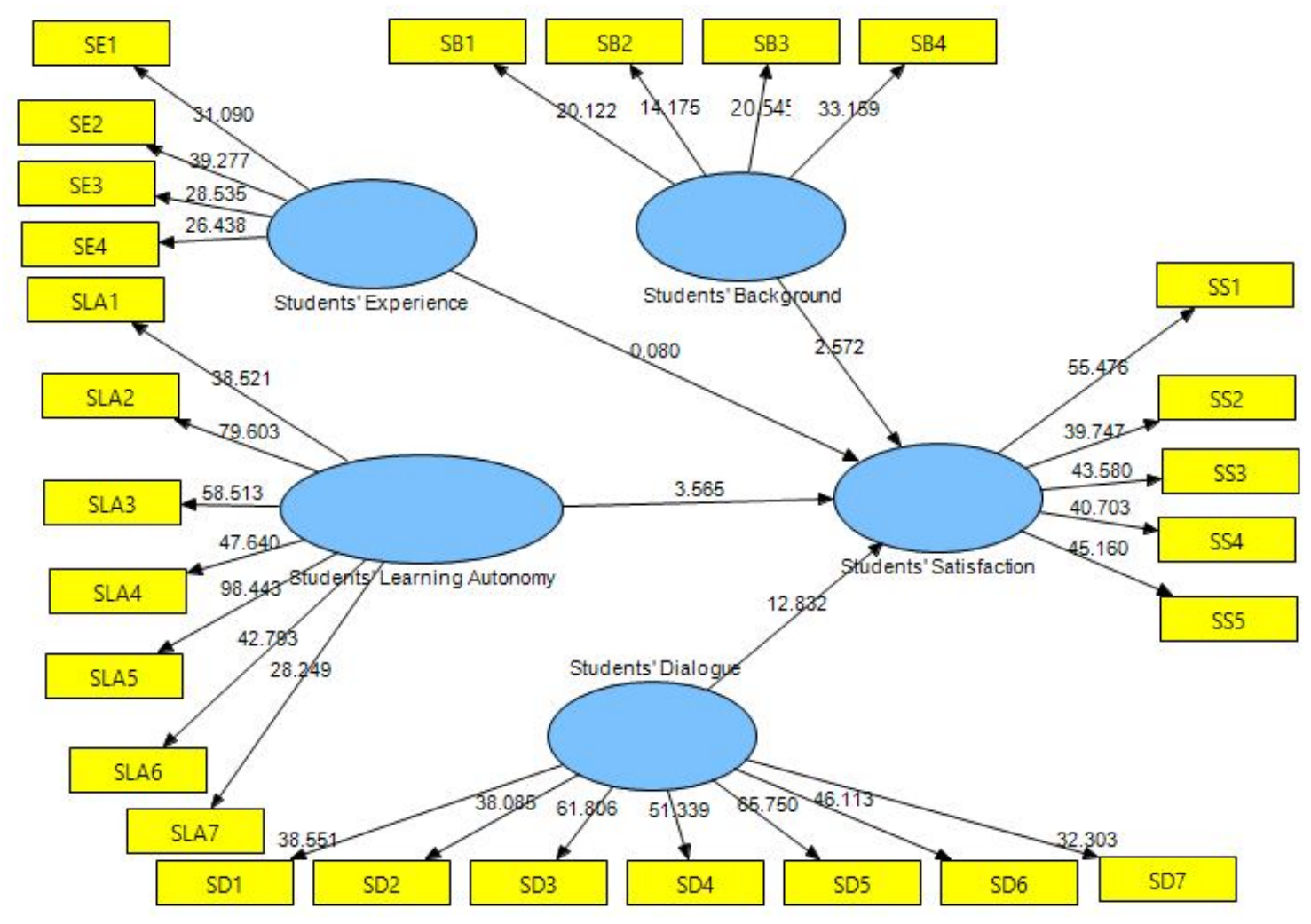

Figure 3: Path Coefficients T Values

Table 4: Hypotheses testing

\begin{tabular}{|l|l|l|l|l|l|l|l|}
\hline H & Independent & Relationship & $\begin{array}{l}\text { Depend } \\
\text { ent }\end{array}$ & $\begin{array}{l}\text { Path } \\
\text { coefficient }\end{array}$ & $\begin{array}{l}\text { Standard. } \\
\text { E }\end{array}$ & T Value & Result \\
\hline 1 & SB & $\longrightarrow$ & SS & 0.114699 & 0.046428 & 2.572468 & Supported \\
\hline 2 & SE & $\longrightarrow$ & SS & 0.004148 & 0.056873 & 0.080931 & Supported \\
\hline 3 & SLA & $\longrightarrow$ & SS & 0.199714 & 0.053834 & 3.565841 & Supported \\
\hline 4 & SD & $\longrightarrow$ & SS & 0.467283 & 0.036615 & 12.832062 & Supported \\
\hline
\end{tabular}

Relate To the first hypothesis, the correlation among students' background and students' satisfaction ( $\beta=0.114699, t=2.572468$, supported). Moreover, second hypothesis was proven to be positive too, significant and supported, as the analysis recommends a correlation among students' experience along with students' satisfaction ( $\beta=0.0 .004148, \mathrm{t}=0.080931$, supported). The next hypothesis is relationship between learning autonomy and students' satisfaction $(\beta=0.199714, \mathrm{t}=3.565841$, supported). Furthermore, hypothesis four was also proven to be positive and supported, as a association exists among students' dialogue along with students' satisfaction ( $\beta=0.467283, t=12.832062$, supported $)$.

\section{DISCUSSION AND IMPLEMENTATIONS}

\subsection{The Effectiveness of the student's background on Web-Based Course}

This data might be supportive for education institutions, administrators and instructors who are conducting training on online course design at their institute. As it presents guidance to the course design developer where students encounter obstacles to completing their online course requirements. Further, the data could inform current online developmental instructors at their education institute who might be creating a new, online, developmental integrated web-based course in their education system. As it relates to TD experienced by the students, instructors in the study might be able to reduce the perception of distance by eliminating some of the navigational obstacle's students encounter in their classes. These finding observed to support [48] finding that facilities provided by the faculty 
and instructor support play a crucial role in distance courses. It also supports the current importance and growth of LMSs in online courses. Perhaps institutions should struggle to provide faculty training to make sure that faculty is aware with flexibilities of all the online courses that are provided to meet the requirements of both instructors and students. When this training implemented properly, perhaps could provide faculty with more flexible means of engaging and interacting students and ultimately contribute in reducing the web-based course for their students, particularly for online courses. In addition, they indicated that technical support, adequacy of equipment, and opportunity for students-to student collaboration played a major role in influencing their decisions to participate in web-based course. The responses are consistent with existing research that has shown that faculty and administrative support tend to influence student participation in online learning environments. [89] noted that the factors of technical support, adequacy of equipment, and opportunity for student-to student collaboration have led to increased student participation in online learning environments. The finding of [51], [52], [53], [54], [55], [99] revealed that Facilities delivered by the faculty increases the interaction among students along with faculty in online learning courses and it has the strongest correlation with student satisfaction with the college experience than any other type of involvement.

\subsection{The Effectiveness of the student's experience on Web-Based Course}

The learners who participated in online course felt more familiar and connected to the course. Results of [47] study, the students were asked: "Have you taken any other online courses at this college? If so, how involved did you feel in this course as compared to other online courses you have taken?". The participants indicated that they have taken an online course before. Those students also indicated that the felt somewhat involved in the online course, as they have participated in a similar setting before. In addition, [58] study on Examining factors affecting ESL learners' approval and usage of Moodle. This study finding reveals that learners who used Moodle before or any other LMSs accepted or consistently much faster than those who didn't have any experience in this regard.

\subsection{The Effectiveness Student's Learning Autonomy on of the Web-Based Course}

In consent with this finding, there are several previous studies of learner autonomy as it relates to selected demographic characteristics have compared age, domestic status, gender, and level of education. In each study there were no significant differences found in the relationship of learner autonomy profile scores and the selected demographic characteristics except for a consistent finding of a relationship between level of education and lab scores [100], [101] [102]; [103], [104], [105]. In contrast, the finding of [106] study showed that learners who have a high level of autonomy were to be expected to choose asynchronous learning environments through online academic sessions and to be repeaters as opposed to learning in the traditional classroom setting. Additionally, students that are repeat asynchronous students are also likely to have a higher level of autonomy in the context of learning. Moreover, results of the research revealed that there is a significant difference in the learner autonomy profile scores for learners undertaking asynchronous learning as repeaters versus those undertaking learning in a traditional learning environment.

\subsection{The Effectiveness of Dialogue on the Web-Based Course}

Regarding capability, frequency and online group activities duration might be a key factor, student interacted with each other once a week. It is most likely that learners didn't find the frequency and duration of group activities to be sufficient to significantly increase their capability with online collaboration [107]. Once conducting an online survey with 150 graduate students having online course experience previously, [108] investigated that the more learners interact among each other, the more they come to be proficient with collaborating online. Moreover, same research explored that students' previous familiarity in online collaboration plays an essential role to influence students' ability with online collaboration [108]. Online learning settings collaboration issues could have affected interest of students in online collaboration. The issues related to online learning environments communication, such as deficiency of face-to-face dialogue, delays in communication and feeling inexperienced regarding technology use for collaboration [49], [46], because online learning environments communication needs technology practice [41]; [109]. In addition, through this experience they could communicate with other participants, regardless of time and location, the process was easy for them, as they had the opportunity to log into Moodle anywhere any time. Unless, if the electricity Blackouts. As the participants mentioned that, this experience provided them with a platform to discuss and share their own ideas with other participants and the instructor.

\subsection{The Effectiveness of Student's Satisfaction on the Web-Based Course}

The analysis of the data showed that the satisfaction among control and experiment group as there is significant differences, which shows that student in the experiment group (web-based course) were at the same level as the traditional (Face-to-face) group. Whereas, these results interpreter that experiment students were at the same level of satisfaction as the traditional group. The researcher considers this finding as a sign of success for online courses. According to [84] found that "the LMS view by more students enhances their satisfaction with the system" and also "technical support has contributed to learner's satisfaction with LMS" (p.193). [85], in a same way, asserted that "the easier learners perceived LMS, the more readily learners accepted LMS" and that "instructors' help 
in using LMSs positively affected learners' acceptance of LMSs" (p.1091). Moreover, in his seminal work, [86] studied data collected from nearly 25,000 students at over 200 higher education institutions. Astin posited that frequent interaction between students and faculty in distance education courses has been more strongly correlated with student satisfaction with the college experience than any other type of engagement [90]. In [88] it was discovered that students discover courses conveyed via online learning effective. According to [88] good collaborations in the community besides getting answers to the education needs will improve their motivation along with learning satisfaction. Also, according to [91] learners who can successfully and comfortably communicate in online settings can be more effective in online settings. In the same way, the findings of this research showed that online communication has positively affected satisfaction towards the course in instruction model. The research model discussed by [92] for English lessons of middle school students also supports these results. According [92] study, it was discovered that there was a positive correlation between communication self-efficacy along with technology self-efficacy with expectations and motivation.

\subsection{Conclusion and Future Work}

University College of Applied Sciences (UCAS) students, who participated in this study defined motivation as one of the salient and significant themes that influence their learning. Generally, finding that have been argued above might be salient related to web-based courses to enhance students' satisfaction and autonomy based on Moore's transactional distance theory (TDT). Consequently, the students were satisfied, and they agreed that web-based courses improve their achievement in relation to students' background, students' experience, students 'learning autonomy, and students' dialogue. Nevertheless, further investigation is needed as to figure out whether this proposed model relates to any other universities, besides, if it does what is the association between a grade and the selection of a particular strategy. Additionally, the impact of learners' satisfaction of education have on the technology acceptance model (TAM) with individual's aim to participate in learning must be emphasized and examined by future study.

\section{REFERENCES}

[1] Lee, S. J., Srinivasan, S., Trail, T., Lewis, D., \& Lopez, S. (2011). Examining the relationship among student perception of support, course satisfaction, and learning outcomes in online learning. Internet and Higher Education, 14(3), 158-163. http://doi.org/10.1016/j.iheduc.2011.04.001

[2] Paechter, M., Maier, B. and Macher, D. (2010) Students' Expectations of and Experiences in ELearning: Their Relation to Learning Achievements and Course Satisfaction. Computers \& Education, 54, 222- 229 .http://dx.doi.org/10.1016/j.compedu.2009.08.005

[3] Song, L., Singleton, E.S., Hill, J.R. \& Koh, M.H. (2004). Improving online learning: Student perceptions of useful and challenging characteristics. Internet and Higher Education, 7(1), 59-70. Elsevier Ltd. https://doi.org/10.1016/j.iheduc.2003.11.003

[4] Mandernach, B. J., Donnelli, E., Amber, D. (2006). Learner Attribute Research Juxtaposed with Online Instructor Experience: Predictors of Success in the Accelerated, Online Classroom. The Journal of Educators Online, 3(2).

[5] Finch, D., \& Jacobs, K. (2012). Online education: Best practices to promote learning. Proceedings of the Human Factors and Ergonomics 56th Annual Meeting.

[6] Al-Rahmi, W., Aldraiweesh, A., Yahaya, N., Bin Kamin, Y., \& Zeki, A. M. (2019a). Massive open online courses (MOOCs): Data on higher education. Data in Brief, 22, 118-125. https://doi.org/10.1016/j.dib.2018.11.139

[7] Al-Rahmi, W., Aldraiweesh, A., Yahaya, N., \& Kamin, Y. B. (2018). Massive open online courses (MOOCS): Systematic literature review in Malaysian higher education. International Journal of Engineering and Technology (UAE), 7(4), 2197-2202.

[8] Bell, B. S., \& Fedeman, J. E. (2013). E-learning in postsecondary education. The Future of Children. https://doi.org/10.1353/foc.2013.0007

[9] West, E., \& Jones, P., (2007). A framework for planning technology used in teacher education programs that serve rural communities. Rural Special Education Quarterly, 26(4), 3-15.

[10]Siemens, G. (2005). Connectivism: A learning theor $\mathrm{y}$ for a digital age. International Journal of Instructiona 1 Technology and Distance Learning, 2(1). Retrieved A ugust

29, 2019, from http://www.itdl.org/Journal/Jan_05/arti cle01.htm

[11]Verhagen, P. (2006). Connectivism: A new learning theory? Retrieved September

10, 2014, from http://elearning.surf.nl/e $\square$ learning/engli $\mathrm{sh} / 3793$

[12]Dede, C., Korte, S., Nelson, R., Valdez, G., \& Ward, D. J. (2005). Transforming lear

ning for the 21st century: An economic imperative. Ret rieved on September10, 2019, from http://www.learnin gpt.org/tech/transforming.pdf

[13] Moskal, P., Dziuban, C., Upchurch, R. Hartman, J. \& Truman, B. (2006). Assessing online learning:What one university learned about student success, persistence, and satisfaction. Peer Review, Fall, 26-29.

[14] Al-Rahmi, W. M., Othman, M. S., \& Yusuf, L. M. (2015a). Effect of engagement and collaborative learning on satisfaction through the use of social media on Malaysian higher education. Research Journal of Applied Sciences, Engineering and Technology, 9(12), 1132-1142.

[15] Cook-Sather, A. (2014). Student-faculty partnership in explorations of pedagogical practice: A threshold concept in academic development. International Journal for Academic Development, 19(3), 186-198. doi: 10.1080/1360144X.2013.805694

[16] Bovill, C., Cook-Sather, A., Felten, P., Millard, L., \& Moore-Cherry, N. (2016). Addressing potential 
challenges in co-creating learning and teaching: Overcoming resistance, navigating institutional norms and ensuring inclusivity in student-staff partnerships. Higher Education, 71(2), 195-208. doi: 10.1007/s10734-015-9896-4

[17] Moore, M. G. (1973). Towards a theory of independent learning and teaching. Journal of Distance Education, 8(6), 1-7. https://doi.org/10.2307/1980599

[18] Moore, M. G. (1993). Theory of transactional distance. In D. Keegan (Ed.), Theoretical principles of distance education (pp. 23-37). London: Routledge.

[19] Moore, M. G. (1972). Learner autonomy: the second dimension of independent learning.

[20] Moore, M. G. (1983). The individual adult learner. In M. Tight (Ed.), Adult learning and education. London: Croom Helm.

[21] Anderson, T., Rourke, L., Garrison, D. R., \& Archer, W. (2001). Assessing teaching presence in a computer conferencing context. Journal of Asynchronous Learning Networks, 5(2), 1-17.

[22] Bischoff, W. R., Bisconer, S. W., Kooker, B. M., \& Woods, L. C. (1996). Transactional distance and interactive television in the distance education of health professionals. American journal of distance education, 10(3), 4-19. doi: $10.1080 / 08923649609526937$.

[23] Chen, Y. J. \& Willits, F. K. (1998). A path analysis of the concepts in Moore's theory of transactional distance in a videoconferencing learning environment. Journal of distance education, 13,51-65.

[24] Chen, Y. J. \& Willits, F. K. (1999). Dimensions of educational transactions in a videoconferencing learning environment. American Journal of distance education, 13,45-59.

https://doi.org/10.1080/08923649909527013

[25] Chen, Y. J. (2001a). Dimensions of transactional distance in the world wide web learning environment: A factor analysis. British journal of education technology, 32, 459-470.

[26] Chen, Y. I. (2001b). Transactional distance in World Wide Web learning environments. Novation in education and training international, 38 ,327-338.

[27] Hillman, C.G., Wills, D.J. \& Gunawardena, C., N. (1994). Learner interface interaction in distance education: an extension of contemporary models and strategies for practitioners, the American journal of distance education 8(2): 30-42.

[28] Jung, D. I. (2001). Transformational and transactional leadership and their effects on creativity in groups. Creativity Research Journal, 13, 185-195.

[29] Kanuka, H. (2001). University students' perceptions of the use of the web in distance delivered programs. The Canadian journal of higher education, 31(3), 4972.

[30] Kanuka, H., Collett, D., \& Caswell, C. (2002). University Instructor Perceptions of the Use of Asynchronous Text-Based Discussion in Distance Courses. The American Journal of Distance Education, $16,151-167$. https://doi.org/10.1207/S15389286AJDE1603 3

[31] Saba, F., Shearer R., L. (1994) Verifying the key theoretical concepts in a dynamic model of distance education The American Journal of Distance Education 8 (1) 36-59.

https://doi.org/10.1080/08923649409526844

[32] Bischoff W. R, Bisconer S., W. et al. (1996) Transactional distance and interactive television in the distance education of health professionals American Journal of Distance Education 10(3) 4-19.

[33] Chen, Y. J., Willits, F., K. (1999) Dimensions of educational transactions in a videoconferencing learning environment American Journal of Distance Education 13(1) 45-59.

[34] Raya, M. J., \& Fernández, J. M. P. (2002). Learner autonomy and new technologies. Educational Media International, 39(1), 61-68. [35] Rickwood \& Goodwin, 2000

[36] Ryan, R. M. (1995). Psychological needs and the facilitation of integrative processes. Journal of Personality, 63, 397-427.

[37] Saba, F. (1996). Dedes distributed learning: A systematic perspective. American journal of distance education, 10(2), 60-64.

https://doi.org/10.1080/08923649609526927

[38] Saba, F., Shearer, R., L. (1994) Verifying the key theoretical concepts in a dynamic model of distance education, The American Journal of Distance Education, 8, 1, 36-59.

[39] White, J. (1995). The concept of intelligence. Journal of education, 29(3).

[40] Moore, M. G., \& Kearsley, G. (1996). Distance education: A systems view. Belmont, CA: Wadsworth Publishing.

[41] Moore, M. G. (2013). The theory of transactional distance. In M. G. Moore (Ed.) Handbook of distance education (3rd ed., pp. 66-85). New York, NY: Routledge.

[42] Gorsky,P., Caspi,A.(2005)Dialogue: a theoretical framework for distance education instructional systems. British Journal of Educational Technology, 36(2), 137-144.

[43] Dewey, J., \& Bentley, A. F. 1949. knowing and the known. Boston: beacon.

[44] Dewey, J. Bentley, A, F. (1989). Knowing and the known, the later works, Carbondale; southern Illinois UP, 5, 241-263

[45] Dewey, J. (1938). Experience and Education. New York: Macmillan Company.

[46] Ko, S., \& Rossen, S. (2017). Teaching online: A practical guide (4th ed.). New York, NY: RoutledgeTaylor Francis. https://doi.org/10.4324/9780203427354

[47] Minor J. I. (2014). Using knowledge of transactional distance theory to Strengthen an online developmental reading course: An action research study. A doctoral dissertation in education. Capella University. United states.

[48] Chen, Y.-J. (2001). Dimensions of transactional distance in the World Wide Web learning environment: A factor analysis. British Journal of Educational Technology, 32(4), 459-470.

[49] Al-Rahmi, W. M., Yahaya, N., Aldraiweesh, A. A., Alamri, M. M., Aljarboa, N. A., Alturki, U., \& Aljeraiwi, A. A. (2019b). Integrating technology acceptance model with innovation diffusion theory: An 
empirical investigation on students' intention to use Elearning systems. IEEE Access, 7, 2697-26809.

[50] Al-Rahmi, W. M., Othman, M. S., \& Yusuf, L. M. (2015c). Exploring the factors that affect student satisfaction through using E-learning in malaysian higher education institutions. Mediterranean Journal of Social Sciences, 6(4S1), 299-310.

[51] Astin, A. W. (1993). What matters in college: Four critical years revisited. San Francisco, CA: JosseyBass.

[52] Ching, Y.-H. (2014). Exploring the impact of roleplaying on peer feedback in an online case-based learning activity. The International Review of Research in Open and Distance Learning, 15, 292-311.

[53] Phirangee, K., Demmans Epp, C., \& Hewitt, J. (2016). Exploring the relationships between facilitation methods, students' sense of community and their online behaviors. Online Learning Journal, 20(2), 134 154. doi: $10.24059 /$ olj.v20i2.775

[54] Shackelford, J. L., \& Maxwell, M. (2012). Contribution of learner--instructor interaction to sense of community in graduate online education. MERLOT Journal of Online Learning and Teaching, 8(4). Retrieved from http://jolt.merlot.org/vol8no4/shackelford_1212.htm

[55] Stoerger, S., \& Kreiger, D. (2016). Transforming a large-lecture course into an active, engaging, and collaborative learning environment. Education for Information,32(1), 11-26. https://doi.org/10.3233/EFI-150967

[56] Brinthaupt, T. M., Fisher, L. S., Gardener, J. G., Raffo, D. M., \& Woodard, J. B. (2011). What the best online teachers should do. MERLOT Journal of Online Learning and Teaching, 7(4),515-524. Retrieved from http://jolt.merlot.org/vol7no4/brinthaupt_1211.htm

[57] Garrison, D. R. (2009). Communities of inquiry in online learning. In P. Rogers, G. Berg, J. Boettcher, C. Howard, L. Justice, \& K. Schenk (Eds.), Encyclopedia of distance learning (2nd ed., pp. 352-355). Hershey, PA: Idea Group.

[58] Rovai, A. P., \& Ponton, M. K. (2005). An examination of sense of classroom community and learning among African American and Caucasian graduate students. Journal of Asynchronous Learning Networks, 9(3), 77-92.

[59] Chau, P. Y. K., \& Hu, P. J. (2002). Examining a model of information technology acceptance by individual professionals: An exploratory study. Journal of Management Information System, 18(4), 191-229.

[60] Moore, G. C., \& Benbasat, I. (1991). Development of an instrument to measure the perception of adopting an information technology innovation. Information System Research, 2(3), 192-223.

[61] Rogers, E.M. (2003). Diffusion of Innovations (5th edition). New York: Free Press.

[62] Taylor, S., Todd, P.A. (1995a). Assessing IT usage: The role of prior experience. MIS Quarterly, 19(2), 561-570.

https://doi.org/10.2307/249633

[63] Lewis R. (2004). Communication technology in the developing nations. Journal of Computer Assisted Learning20, pp159
[64] Al Mahmud, A. (2011). Students' attitudes towards Internet: A study on private universities of Bangladesh. European Journal of Business and Management, 3(6), 9-19.

[65] Al Otaibi, K. N. (2012). Attitudes towards the use of the Internet. Psychology Research, 2(3), 151-159.

[66] Oshan, M. S., \& Khudair, A. A. (2008). King Saud University students' attitude towards the Internet: Experience and gender issues. Information Studies, 3, 1-29.

[67] Tekynarslan, E. (2008). Faculty of education students' attitudes toward Internet and implications for online learning. Abant İzzet Baysal Üniversitesi Eğitim Fakültesi Dergisi, 8(1), 67-82.

[68] Tsai, C.-C., Lin, S. S. J., \& Tsai, M.-J. (2001). Developing an Internet attitude scale for high school students.

Computers \& Education, 37(1), 41-51. https://doi.org/10.1016/S0360-1315(01)00033-1

[69] Olson, G. M. (2000). Distance matters. humancomputer interaction, 2000, volume 15, pp. 139-178

[70] Falloon, G. (2011). Making the connection: Moore's theory of transactional distance and its relevance to the use of a virtual classroom in postgraduate online teacher education. Journal of Research on Technology in Education, 43(3), 187-209.

[71] Ryan, T., Toye, M., Charron, K., \& Park, G. (2012). Learning management system migration: An analysis of stakeholder perspectives. International Review of Research in Open \& Distance Learning, 13(1), 220237.

[72] Lopez-Perez, M.V., Perez-Lopez, M.C. \& Rodriguez-Ariza, L. (2011). Blended learning in higher education: Students' perceptions and their relation to outcomes. Computers \& Education, 56(3), 818-826.

[73] Hung, M. L., Chien C., Chen, C. H. \& Own, Z. U. (2010). Learner readiness for online learning: Scale development and student perceptions. Computers \& Education, 1080-1090

[74] Owston, R.,York, D., \& Murtha, S. (2012). Students perceptions and achivemnt in a university blended learning strategic initiative. The internet and higher education, 18,38-46.

[75] Abulibdeh, E. S., Ishtaiwa, F. F., (2012). The impact of asynchronous e-learning tools on interaction and learning in a blended course. International journal of instructional media, 39(2), 141-159.

[76] Saba, F. (2013). Building the future: a theoretical perspective. In M. Moore (Ed), handbook of distance education (pp. 49-65). New York, NY: Routledge.

[77] Bajt, S., K. (2009). Preferred distance learning modalities of Millennial community college students, University of Illinois at Urbana-Champaign.

[78] Tian, R. G. \& Wang, C. H. (2012). Cross cultural customer satisfaction at a Chinese restaurant: the implications to china food service marketing. International Journal of China Marketing.

[79] Sinclaire, J. K. (2011). Student satisfaction with online learning: Lessons from organizational behavior. Research in Higher Education Journal.

[80] Abdous, M., \& Cherng-Jyh, Y. (2011). A predictive study of learner satisfaction and outcomes in face-to- 
face, satellite broadcast, and live video-streaming learning environments. Internet and Higher Education.

[81] Moore, M., \& Kearsley, G. (2012). Distance education: A systems view of online learning (thirdEd.). Belmont, CA: Wadsworth Cengage Learning.

[82] Abou Naaj, M., Nachouki, M., \& Ankit, A. (2012). Evaluating student satisfaction with blended learning in a gender-segregated environment. Journal of Information Technology Education: Research. https://doi.org/10.28945/1692

[83] Kardo, J. M. (2015). Reaching all through open and distance learning in Tanzania. Chanakya International Journal of Business Research.

[84] Green, L.S., Inan, F.A., \& Denton, B. (2012). Examination of factors impacting student satisfaction with a new learning management system. Turkish Online Journal of Distance Education, 13(3), 189-197.

[85] Escobar-Rodriguez, T., \& Monge-Lozano, P. (2012). The acceptance of Moodle technology by business administration students. Computer \& Education, 58, 1085- 1093.

[86] Astin, W. A. (1999). Student involvement: A development theory for higher education. Journal of College Student Development,40, 231-247.

[87] Caliskana, S., \& Suzekb, S., \& Ozcanb, D. (2017). Determining student satisfaction in distance education courses. 9th International Conference on Theory and Application of Soft Computing, Computing withWords and Perception, ICSCCW 2017, 24-25 August 2017, Budapest, Hungary

[88] Yalman, m. (2013). Eğitim fakültesi öğrencilerinin bilgisayar destekli uzaktan eğitim sistemi (moodle) memnuniyet düzeyleri. Electronic turkish studies, 8(8).

[89] Al-Rahmi, W. M., Alias, N., Othman, M. S., Ahmed, I. A., Zeki, A. M., \& Saged, A. A. (2017). Social media use, collaborative learning and students' academic performance: A systematic literature review of theoretical models. Journal of Theoretical and Applied Information Technology, 95(20), 5399-5414.

[90] Al-Rahmi, W. M., Othman, M. S., \& Yusuf, L. M. (2015b). Using social media for research: The role of interactivity, collaborative learning, and engagement on the performance of students in Malaysian postsecondary institutes. Mediterranean Journal of Social Sciences, 6(5S2), 536-546.

[91] Gülbahar, Y. (2009). E-learning. Ankara: Pegem A Publication.

[92] Minor Hao, Y. (2016b). Middle school students' flipped learning readiness in foreign language classrooms: Exploring its relationship with personal characteristics and individual circumstances. Computers in Human Behavior, 59, 295-303.

[93] Hung, M.-L., Chou, C., Chen, C.-H., \& Own, Z.-Y. (2010). Learner readiness for online learning: Scale development and student perceptions. Computers \& Education, 55(3), 1080-1090.

[94] Owston, R., York, D., \& Murtha, S. (2012). Student perceptions and achievement in a university blended learning strategic initiative. The Internet and Higher Education, 18, 38-46.

[95] Hair, J. F., Hollingsworth, C. L., Randolph, A. B., and Chong, A. Y. L (2017). An Updated and Expanded
Assessment of PLS-SEM in Information Systems Research. Industrial Management \& Data Systems, 117(3): 442-458.

https://doi.org/10.1108/IMDS-04-2016-0130

[96] Fornell, C., \& Larcker, D. F. (1981). Evaluating structural equation models with unobservable variables and measurement error. Journal of marketing research, 18(1), 39-50.

[97] Bagozzi, R. P., Yi, Y., \& Nassen, K. D. (1998). Representation of measurement error in marketing variables: Review of approaches and extension to three-facet designs. Journal of Econometrics, 89(1-2), 393-421.

[98] Sammons, P. (1999) School Effectiveness: coming of age in the twenty-first century. Lisse: Swets and Zeitlinger.

[99] Sun, A., \& Chen, X. (2016). Online education and its effective practice: A research review. Journal of Information Technology Education: Research, 15, 157$190 . \quad$ Retrieved from http://www.informingscience.org/Publications/3502

[100] Carr PB (1999). The measurement of resourcefulness intentions in the adult autonomous learner (Doctoral dissertation, The George Washington University, 1999). Dissertation Abstracts International, 60(11), 3849A.

[101] Derrick MG (2001). The measurement of an adult's intention to exhibit persistence in autonomous learning. (Doctoral dissertation. The George Washington University, 2001). Dissertation Abstracts International, 62(5): 2533B.

[102] Meyer DA (2001). The measurement of intentional behavior as a prerequisite to autonomous learning. (Doctoral dissertation, The George Washington University, Washington, DC, 2001). Dissertation Abstracts International. 61(12): 3933A.

[103] Phillips AD (2004). An assessment of the learner autonomy of students enrolled in academic and vocational programs at Thomas Nelson Community College (Virginia). (Doctoral dissertation, The George Washington University, 2004). Dissertation Abstracts International. (64):11. 3975A.

[104] Ponton MK (1999). The measurement of an adult's intention to exhibit personal initiative in autonomous learning. (Doctoral dissertation, The George Washington University, 1999). Dissertation Abstracts International, 60(11): 3933A.

[105] Wilson DM (2004). The correlation between racial identity development and learner autonomy of African American students (Virginia). (Doctoral dissertation, The George Washington University, 2004). Dissertation Abstracts International, (65)07, 2467A.

[106] Davis R., B., S. (2006). Learner Autonomy Profiles of Adult Learners in Asynchronous Learning Environments Versus the. Doctorate dissertation, George Washington University. USA.

[107] Brindley, J., Blaschke, L. M., \& Walti, C. (2009). Creating effective collaborative learning groups in an online environment. The International Review of Research in Open and Distributed Learning, 10(3),118.

https://doi.org/10.19173/irrodl.v10i3.675 
[108] Lee, S., \& Tsai, C. (2011). Students' perceptions of collaboration, self-regulated learning, and information seeking in the context of Internet-based learning and traditional learning. Computers in Human Behavior, 27(2), 905-914. https://doi.org/10.1016/j.chb.2010.11.016

[109] Thurmond, V. A., Wambach, K., Connors, H. R., $\&$ Frey, B. B. (2002). Evaluation of student satisfaction: Determining the impact of a web-based environment by controlling for student characteristics. American Journal of Distance Education, 16(3), 169190.

https://doi.org/10.1207/S15389286AJDE1603_4 